\title{
Evaluation of the Nutritional Status and Phytomedicinal Properties of Dried Rhizomes of Turmeric (Curcuma longa)
}

\author{
Victor Henry Azubuike Enemor, Uchechukwu Chibuzo Ogbodo*, Ogechukwu Frances Nworji, \\ Obiajulu Christian Ezeigwe, Chukwuemeka Obumneme Okpala, \\ Gloria Chiamaka Iheonunekwu
}

Department of Applied Biochemistry, Nnamdi Azikiwe University, Awka, Nigeria

Email: *uc.ogbodo@unizik.edu.ng

How to cite this paper: Enemor, V.H.A., Ogbodo, U.C., Nworji, O.F., Ezeigwe, O.C., Okpala, C.O. and Iheonunekwu, G.C. (2020) Evaluation of the Nutritional Status and Phytomedicinal Properties of Dried Rhizomes of Turmeric (Curcuma longa). Journal of Biosciences and Medicines, 8 , 163-179.

https://doi.org/10.4236/jbm.2020.88015

Received: June 17, 2020

Accepted: August 22, 2020

Published: August 25, 2020

Copyright $\odot 2020$ by author(s) and Scientific Research Publishing Inc. This work is licensed under the Creative Commons Attribution International License (CC BY 4.0).

http://creativecommons.org/licenses/by/4.0/

\begin{abstract}
Turmeric (Curcuma longa) belongs to the family Zingiberaceae and has long been used traditionally for centuries as a spice and medicinal elixir. Hence, the present study aimed to profile the nutritional and phytomedicinal properties of the plant in order to justify its relevance in traditional phytomedicine and advocate its application in novel pharmacological products. Using standard methods (High Performance Liquid Chromatography, Gas Chromatography-Mass Spectroscopy and Atomic Absorption Spectrophotometry), the dried rhizomes were washed, pulverized and ethanol extracts subjected to proximate, phytochemical, vitamins, amino acid and mineral determinations. Data obtained were analyzed using student's $t$-test in Statistical Package for the Social Sciences version 21. Determined proximate indices indicated moisture content of $9.55 \%$, carbohydrate $(57.30 \%)$, ash (24.70\%), crude fiber $(1.12 \%)$, proteins $(2.15 \%)$ and fat $(5.32 \%)$. Mineral composition analyses showed that $C$. longa rhizomes had higher contents of calcium, magnesium, potassium and sodium in parts per million (ppm) at $38.68 \pm 0.114,19.75 \pm$ $0.001,9.20 \pm 0.002$ and $7.06 \pm 0.014$ respectively. Amino acid profile revealed the presence of both essential and non-essential types with aspartate and glutamate in higher contents at $9.78 \mathrm{~g} / 100 \mathrm{~g}$ and $9.65 \mathrm{~g} / 100 \mathrm{~g}$, respectively. Findings showed also the presence of vitamins A, C and D at $254.5 \pm 2.19$ $\mathrm{mg} / \mathrm{kg}, 19.47 \pm 0.16 \mathrm{mg} / \mathrm{kg}$ and $10.92 \pm 0.92 \mathrm{mg} / \mathrm{kg}$, respectively. Phytochemical analyses showed the presence of phenolic compounds with high retention times. This study thus revealed that $C$. longa possesses various nutritional and pharmacological/medicinal components in considerable quantities and can provide the body with basic nutrients for its therapeutic needs as well as secondary compounds with tremendous phytomedicinal potentials.
\end{abstract}




\section{Keywords}

Curcuma longa, Nutritional, Phytomedicine, Traditional, Rhizomes

\section{Introduction}

Plants from time immemorial have been a source of supply for the basic nutritional requirements of the body primarily for metabolic and physiological functions. With the rising incidence of food insecurity and scourge of "hidden" hunger of most micronutrients prevalent in the developing countries, more plants that have aforetime not been exploited for their nutritional benefits are receiving more attention. According to Ononamdu et al. [1], historically plants have been the basis of the most traditional and modern ethnobotanical treatment systems the world over. A vast array of indigenous plants has been employed in the treatment and management of various ailments and illnesses including plants that have served as mere spices for cooking. Enemor et al. [2] noted that evidences are also beginning to emerge that even plant seeds hitherto neglected possess, tremendous nutritional and pharmacological potentials. Such plants have not been sufficiently exploited for their nutritional components and potential phytoethnomedicinal properties, hence the need for this study. Due to the increasing popularity of traditional medicine [1], scientific investigations into the phytochemical components of these plants are progressively been demonstrated by several authors [3]. Despite its numerable use in industries, medicine, pharmacology, food and cosmetology as documented by Prasad and Aggarwal [4], Curcurma longa yet continues to top the list of under-exploited plants in the South-east region of Nigeria.

C. longa (turmeric) is a medicinal plant that botanically belongs to Zingiberaceae family, explained in studies published by Chattopadhyan et al. [5], Jilani et al. [6], Olatunde et al. [7] and Taoheed et al. [8]. Nwaekpe et al. [9], Chanda and Ramachandra [10] described the plant as a rhizomatous perennial erect leafy herb that measures up to 1 meter high with a short stem, having oblong, pointed leaves and funnel-shaped yellow flowers. The turmeric plant thrives in temperatures between $20^{\circ} \mathrm{C}$ and $30^{\circ} \mathrm{C}$ and a considerable amount of annual rainfall. In Nigeria, C. longa grows 5 meters above sea level in the Southern coastal plains of the rainforest to the 823 meters above sea level in the Savanna, as reported by Olojede and Nwokocha [11] and it is variously known in local contexts as atale pupa in Yoruba; gangamau in Hausa; ohu boboch in Nkanu East, Enugu; gigir in Tiv; and onjonigho in Cross River State in studies documented by Nwaekpe et al. [9] and Olojede and Nwokocha [11]. The turmeric rhizome is tuberous with a rough and segmented skin and matures beneath the foliage in the ground. The rhizomes are yellowish brown with a dull orange interior and can be ground, when dried, to a yellow powder with a bitter, slightly acrid, yet sweet, taste. 
Luthra et al. [12] noted that $C$. longa is widely used both as spice and coloring agent and is believed by many to possess medicinal properties. There are existing reports that turmeric powder has been applied as traditional medicine against gastrointestinal diseases, especially for biliary and hepatic disorders, diabetic wounds, rheumatism, inflammation, sinusitis, anorexia, coryza and cough. $C$. longa acts as anticancer as reported by Abdel-Lateef et al. [13], anti-diabetic, antioxidant, hypolipidemic, anti-inflammatory, antimicrobial, anti-fertility, anti-venom, hepatoprotective, nephroprotective, anticoagulant agent and possesses anti-HIV activity to combat AIDS as described by Akram [14].

While turmeric may be said to be a medicinal elixir based on the range of ailments alluded to its efficacy, much of our insight of its attributes in disease conditions depends on quality scientific evaluations, hence the need to profile the nutritional and bioactive components of the plant, grown on the Nigerian soil, for a better delineation of the properties that make for its claim in pharmacology and traditional medicine while including the plant into the daily fare of the locale.

\section{Materials and Methods}

\subsection{Source of Plant Material and Identification}

Fresh rhizomes of $C$. longa used in this work were obtained from Eke Awka market, Awka South Local Government Area, Anambra State, Nigeria and identified by a taxonomist with the Department of Botany, Nnamdi Azikiwe University, Awka, Anambra State.

\subsection{Experimental Site}

The experimental analyses were carried out at Laboratory of the Department of Applied Biochemistry, Nnamdi Azikiwe University, Awka and Multi-user Science Laboratory, Zaria, Kaduna State.

\subsection{Preparation of Plant Material}

The harvested rhizomes were carefully washed with clean water. They were then peeled, steamed for 10 minutes to remove the raw odour. It was later dried in the oven at a temperature of $65^{\circ} \mathrm{C}$. After drying, the rhizomes were milled into powder and tightly packaged in a polythene bag kept at room temperature until required for use.

\subsection{Determination of Proximate Composition}

The crude protein, moisture, crude fiber, and fat contents of the sample were determined according to the methods of Association of Official Analytical Chemists [15]. Determination of ash content was done by ashing at $550^{\circ} \mathrm{C}$ for 3 hours. The Kjeldah method was employed to determine the crude protein content. The crude fiber content was determined by digestion method and crude fat content was determined by Soxhlet extraction method. Total soluble carbohy- 
drate was determined by the difference of the sum of all the proximate compositions from $100 \%$.

\subsection{Determination of Phytochemicals (GC-MS Analysis)}

The GC-MS analysis of bioactive compounds from the different extracts of the leaves was done using Agilent Technologies GC systems with GC-7890A/ MS-5975C model (Agilent Technologies, Santa Clara, CA, USA) equipped with HP-5MS column ( $30 \mathrm{~m}$ in length $\times 250 \mu \mathrm{m}$ in diameter $\times 0.25 \mu \mathrm{m}$ in thickness of film). Spectroscopic detection by GC-MS involved an electron ionization system which utilized high energy electrons $(70 \mathrm{eV})$. Pure helium gas $(99.995 \%)$ was used as the carrier gas with flow rate of $1 \mathrm{~mL} / \mathrm{min}$. The initial temperature was set at $50^{\circ} \mathrm{C}-150^{\circ} \mathrm{C}$ with increasing rate of $3^{\circ} \mathrm{C} / \mathrm{min}$ and holding time of about 10 min. Finally, the temperature was increased to $300^{\circ} \mathrm{C}$ at $10^{\circ} \mathrm{C} / \mathrm{min}$. One microliter of the prepared $1 \%$ of the extracts diluted with respective solvents was injected in a split-less mode. Relative quantity of the chemical compounds present in each of the extracts of B. luzonica was expressed as percentage based on peak area produced in the chromatogram.

\section{Identification of Chemical Constituents}

Bioactive compounds extracted from different extracts of $B$. luzonica were identified based on GC retention time on HP-5MS column and matching of the spectra with computer software data of standards (Replib and Mainlab data of GC-MS systems).

\subsection{Determination of Vitamins}

Vitamins $\mathrm{A}, \mathrm{C}$ and $\mathrm{E}$ were determined respectively by the calorimetric, titrimetric and Futter-Mayer colorimetric methods of Kirk and Sawyer [16] with absorbance measured at $325 \mathrm{~nm}$ and $410 \mathrm{~nm}$ for Vitamins A and E respectively. Vitamins $B_{1}$ and $B_{2}$ were estimated spectrophotometrically at $216 \mathrm{~nm}$ and 242 $\mathrm{nm}$ respectively. Vitamins $\mathrm{B}_{3}$ and $\mathrm{B}_{6}$ were titrated to greenish blue and green colour end-points using $0.1 \mathrm{ml}$ perchloric acid and $2-3$ drops of crystal violet as indicator while vitamin $B_{12}$ content was measured spectrophotometrically at 361 $\mathrm{nm}$ by the method of Kirk and Sawyer [16]. Vitamins D and K were determined spectrophotometrically at $450 \mathrm{~nm}$ and $503 \mathrm{~nm}$ respectively using the methods as described by Zakaria et al. [17].

\subsection{Determination of Minerals}

Heavy metal contents were determined using Varian AA240 Atomic Absorption Spectrophotometer according to the methods described by American Public Health Association [18].

\subsection{Amino Acid Profile (HPLC Analysis)}

Sample proteins were hydrolyzed prior to derivatization. A $0.1 \mathrm{~g}$ lyophilized sample was weighed into a 16- $\times 125-\mathrm{mm}$ screw-cap Pyrex (Barcelona, Spain) 
tube, $15 \mathrm{~mL}$ of $6 \mathrm{~N}$ hydrochloric acid was added, and the tube was thoroughly

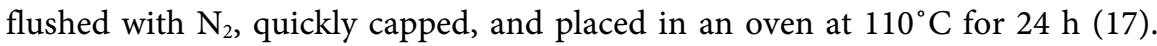
After hydrolysis, the tube contents were vacuum filtered (Whatman \#541, Maidstone, England) to remove solids, the filtrate was made up to $25 \mathrm{~mL}$ with water, and an aliquot of this solution was further filtered through a $0.50-\mu \mathrm{m}$ pore-size membrane (Millipore, Madrid, Spain). A standard solution containing 1.25 $\mu \mathrm{mol} / \mathrm{mL}$ of each amino acid in $0.1 \mathrm{~N}$ hydrochloric acid was created. Derivatization of sample was done by the method of AOAC as described by Elkin and Griffin [19].

\subsection{Data Analysis}

Data was subjected to statistical analyses using Statistical Package for the Social Sciences International Business Machine (SPSS IBM) version 21.0 (SPSS Inc., Illinois Chicago, USA). Data were presented as mean \pm SD of triplicate determinations.

\section{Results and Discussion}

\subsection{Proximate Analysis of $C$. longa}

The values represented in Table 1 show that the turmeric plant under proximate analysis had $9.55 \pm 1.20,24.70 \pm 1.56$ and $1.12 \pm 0.03$ of moisture, ash and fiber respectively. The findings also showed fat, protein and carbohydrates contents of $5.32 \pm 1.23,2.15 \pm 0.07$ and $57.30 \pm 1.69$ respectively. Similarly the findings of this study corresponded with that of previous studies on turmeric conducted by Ikpeama et al. [20] and Imoru et al. [21]. This indicates that the plant could be good sources of carbohydrates and fat when compared to mean carbohydrate values obtained for other species of Curcuma such as $C$. amada, C. leucorrhiza, C. pseudomontana and plants usually employed for culinary purposes, reported in studies conducted by Rajkumari and Sanatombi [22]. The protein content was found to be $2.15 \% \pm 0.07 \%$ in the present study. Protein is an essential component of human diet needed for the replacement of tissues, supply of energy and adequate amount of required amino acids for various biosynthetic molecules. Proteins are also required in synthesis of enzymes, hormones and antibodies [23]. Similarly, the high content of ash $(24.70 \pm 1.56)$ compares favorably with

Table 1. Proximate analysis of C. longa.

\begin{tabular}{cc}
\hline Parameters & Mean \pm Standard Deviation (\%) \\
\hline Ash & $24.70 \pm 1.56$ \\
Carbohydrate & $57.30 \pm 1.69$ \\
Fat & $5.32 \pm 1.23$ \\
Fiber & $1.12 \pm 0.03$ \\
Moisture content & $9.55 \pm 1.20$ \\
Protein & $2.15 \pm 0.07$
\end{tabular}

Values are mean \pm standard deviation of triplicate determinations. 
values obtained for other Curcuma species and suggests that $C$. longa may be a potent source of minerals both major and trace. The crude fiber content of $C$. longa in the present study may suggest its detoxifying ability by removing potential carcinogens from the body, helps in bowel movement and prevents the absorption of excess cholesterol. Fiber adds bulk to food and prevents the intake of excess starchy food and may therefore guard against digestive tract metabolic conditions such as hypercholesteremic and diabetes mellitus [24]. Ayoola and Adeyeye [25] further explained that fiber also softens stool and therefore prevents constipation thus helping to fight colon cancer.

\subsection{Vitamin Contents of $C$. longa}

The vitamin analysis of the plant as represented in Table 2 showed a high mean content of vitamin A at $254 \pm 2.19$ followed by vitamins $C$ and D at $19.47 \pm 0.16$ and $10.92 \pm 0.92$ respectively. In the same vein, the analysis revealed that the rhizome contained vitamin $\mathrm{B}_{1}, \mathrm{~B}_{2}, \mathrm{~B}_{3}, \mathrm{~B}_{6}$ and $\mathrm{B}_{12}$ at $1.98 \pm 0.01,2.18 \pm 0.00,2.25$ $\pm 0.15,0.08 \pm 0.00$ and $1.24 \pm 0.00$ respectively. Vitamin $\mathrm{K}$ was estimated at 7.08 +0.02 in the plant. These findings corroborate previous studies of nutritional composition carried out on $C$. longa with similar values of Vitamins A, C and E in the rhizomes of the plant documented by Ikpeama et al. [20] and Imoru et al. [21]. Vitamin A content higher than that obtained for the present study was reported by Imoru et al. [21] whereas Ikpeama et al. [20] observed a lower value of $B_{1}, B_{2}$ and $B_{3}$ than the values of the study. These disparities may be due to the different methods employed in determination of the vitamin contents or differences in soil composition. The presence of vitamins in $C$. longa may elucidate its involvement as an antioxidant and anticancer agent in traditional phytomedicine and further implicate it as an ingredient in novel pharmacology products.

\subsection{Mineral Content of $C$. longa}

The mineral contents of $C$. longa are presented in Table 3. It contains Ca (38.689

Table 2. Vitamin contents of $C$. longa.

\begin{tabular}{cc}
\hline Parameters & Mean \pm Standard Deviation $(\mathbf{m g} / \mathbf{k g})$ \\
\hline Vitamin A & $254.5 \pm 2.19$ \\
Vitamin $B_{1}$ & $1.98 \pm 0.01$ \\
Vitamin $B_{2}$ & $2.18 \pm 0.00$ \\
Vitamin B $_{3}$ & $2.25 \pm 0.15$ \\
Vitamin $B_{6}$ & $0.08 \pm 0.00$ \\
Vitamin $B_{12}$ & $1.24 \pm 0.00$ \\
Vitamin C & $19.47 \pm 0.16$ \\
Vitamin D & $10.92 \pm 0.92$ \\
Vitamin E & $0.94 \pm 0.01$ \\
Vitamin K & $7.08 \pm 0.02$ \\
\hline
\end{tabular}

Values are mean \pm standard deviation of triplicate determinations. 
Table 3. Mineral composition of $C$. longa.

\begin{tabular}{cc}
\hline Parameter & Mean \pm Standard Deviation (ppm) \\
\hline Aluminum & $0.187 \pm 0.003$ \\
Arsenic & $1.496 \pm 0.005$ \\
Cadmium & $0.000 \pm 0.000$ \\
Calcium & $38.689 \pm 0.114$ \\
Chromium & $0.295 \pm 0.004$ \\
Cobalt & $0.114 \pm 0.006$ \\
Copper & $0.153 \pm 0.009$ \\
Iron & $0.708 \pm 0.001$ \\
Lead & $0.374 \pm 0.002$ \\
Magnesium & $19.750 \pm 0.001$ \\
Manganese & $1.446 \pm 0.044$ \\
Mercury & $0.126 \pm 0.003$ \\
Nickel & $0.226 \pm 0.003$ \\
Potassium & $9.204 \pm 0.002$ \\
Selenium & $0.000 \pm 0.000$ \\
Sodium & $7.060 \pm 0.014$ \\
Vanadium & $0.000 \pm 0.000$ \\
\hline
\end{tabular}

Values are mean \pm standard deviation of triplicate determinations.

$\pm 0.114)$ as the highest element followed by $\mathrm{Mg}(19.75 \pm 0.001)$ and $\mathrm{K}(9.204 \pm$ $0.014)$. The rhizome also contains some heavy metals in considerable quantities such as $\mathrm{Pb}(0.374+0.002), \operatorname{Ar}(1.496 \pm 0.005), \mathrm{Ni}(0.226 \pm 0.003)$ and $\mathrm{Hg}(0.126$ $\pm 0.003)$. These contents are significant of the nutritive value of $C$. longa. Calcium, as a micronutrient, plays a part in the regulation of muscle contraction and relaxation and is implicated in strong bones and teeth development [20] [26]. Normal extracellular calcium concentration is necessary for blood coagulation as explained by Ogidi et al. [23] and Okaka and Okaka [27]. The magnesium content of the plants was found to be $19.75 \pm 0.001$, considerably high in support of previous works on the plant. In a research publication by Hartwig [28], magnesium plays fundamental roles in genomic stability and DNA repair processes. Magnesium activates over 300 different enzymes and thus participates in many metabolic processes, which makes it a pivotal micronutrient, as well as functions in electrolyte transport across cell membranes [29] [30]. Several studies showed that magnesium ions are important for maintaining cell homeostasis because they are essential to the stabilization of cell membranes, especially in the red blood cells where they help maintain membrane integrity through the action of the potassium and calcium pumps [30] [31] [32]. With such significant roles and its presence in the plant, this may elucidate the involvement of the plant in phytomedicine as a blood purifier.

Potassium content which was also observed to be high $(9.204 \pm 0.014)$ in this study supported previous reports [33] of its presence in most agricultural plants. It helps to maintain body weight and regulate water and electrolyte balance in the blood and tissues thereby controlling blood pressure [34]. It is also involved 
in regulating muscle contraction and nerve impulse transmission [20]. Sodium was also found to be a mineral constituent of the dried rhizomes under analysis $(7.06 \pm 0.014)$ and its presence may have implicative functions in treatment of heart diseases as was indicated by Ogidi et al. [23].

Trace amount of manganese $(1.446 \pm 0.044)$ was observed in the plant as shown by the present study. Manganese is involved in activating enzyme-catalyzed reactions such as decarboxylations, phosphorylations, reductions and hydrolysis reactions. Manganese regulates blood sugar levels, the production of energy and cell reproduction. It may be involved as a cofactor in enzymes of oxidative stress such as superoxide dismutase.

The presence of heavy metals such as lead, mercury, arsenic, nickel and mercury as observed in the present study may probably explain the role of the plant in phytoremediation or the bio-concentration of these metals in the soil from where the plant rhizome were obtained. It may also indicate the degree of environmental contamination in the farm area though the amounts sequestered in the dried rhizomes under study are minimal compared to amounts obtained in areas of dense environmental pollution or plants of phytoremediation. Since heavy elements may have little or no beneficial biochemical roles or biological functions, its presence may be for the benefit of the plant in secondary metabolic processes requiring the elements.

\subsection{Amino Acid Profile of C. longa}

The amino acid profile of the plant is presented in Table 4. Eighteen out of the

Table 4. Amino acid profile.

\begin{tabular}{|c|c|}
\hline Amino acid & Concentration (g/100 g of Protein) \\
\hline Alanine & 2.34 \\
\hline Arginine & 6.55 \\
\hline Aspartate & 9.78 \\
\hline Cystine & 2.74 \\
\hline Glutamate & 9.65 \\
\hline Glycine & 3.64 \\
\hline Histidine & 4.76 \\
\hline Isoleucine & 2.85 \\
\hline Leucine & 2.65 \\
\hline Lysine & 3.85 \\
\hline Methionine & 1.50 \\
\hline Phenylalanine & 5.75 \\
\hline Proline & 3.69 \\
\hline Serine & 3.74 \\
\hline Threonine & 3.57 \\
\hline Tryptophan & 1.79 \\
\hline Tyrosine & 2.92 \\
\hline Valine & 4.75 \\
\hline
\end{tabular}

Values are mean \pm standard deviation of triplicate determinations. 
twenty amino acids were identified in the analysis. Amino acid composition of protein isolates is an indicator of their nutritive value. The concentrations of essential amino acids and non-essential amino acids of isolated protein were present. The isolated protein contained ten essential amino acids and eight non-essential amino acids of the twenty amino acids. These data showed that the plant had a complete protein fraction. Of the essential amino acids present, arginine $(6.55 \mathrm{~g} / 100 \mathrm{~g})$ was found maximum while glutamate $(9.65 \mathrm{~g} / 100 \mathrm{~g})$ was presented maximum as a non-essential amino acid in the isolated protein. Overall, aspartate $(9.78 \mathrm{~g} / 100 \mathrm{~g})$ was found in higher concentration followed by glutamate $(9.65 \mathrm{~g} / 100 \mathrm{~g})$ and arginine $(6.55 \mathrm{~g} / 100 \mathrm{~g})$. In a previous study, Enemor et al. [2] indicated that the presence of the essential amino acids in the plant under analysis may demonstrate its potential and involvement in body building activities, cell proliferation and stabilization of protein complexes in wound healing. Figure 1 shows the chromatogram obtained for the amino acid profiling of $C$. longa.

\subsection{Phytochemical Composition of C. longa}

The present study identified several phenolic compounds with varying retention times as obtained by GC-MS analysis presented in Table 5. Figures 2-5 show

Print of windoe 38: Current Chromatogram (s)

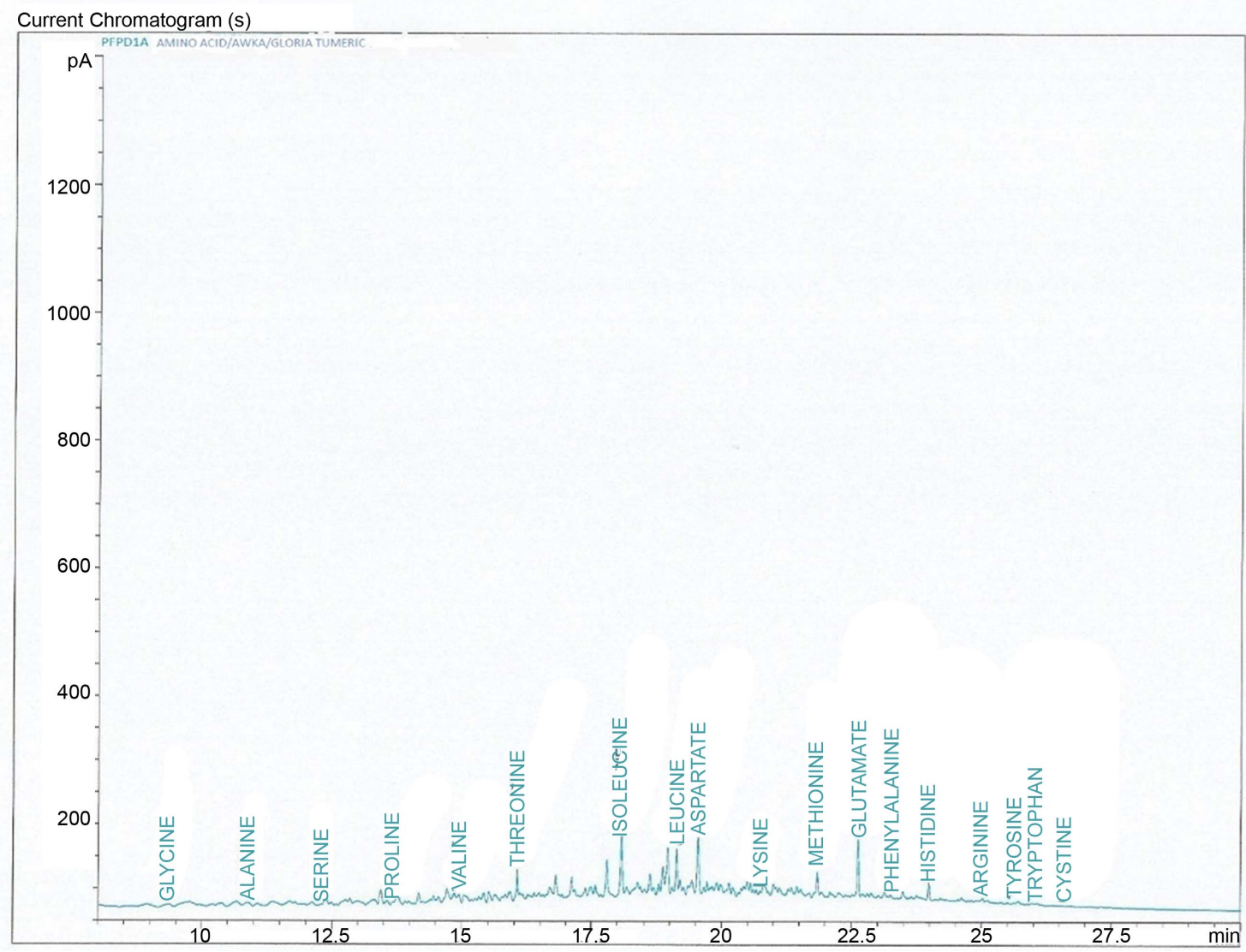

Figure 1. Amino acid chromatogram of C. longa. 
Abundance

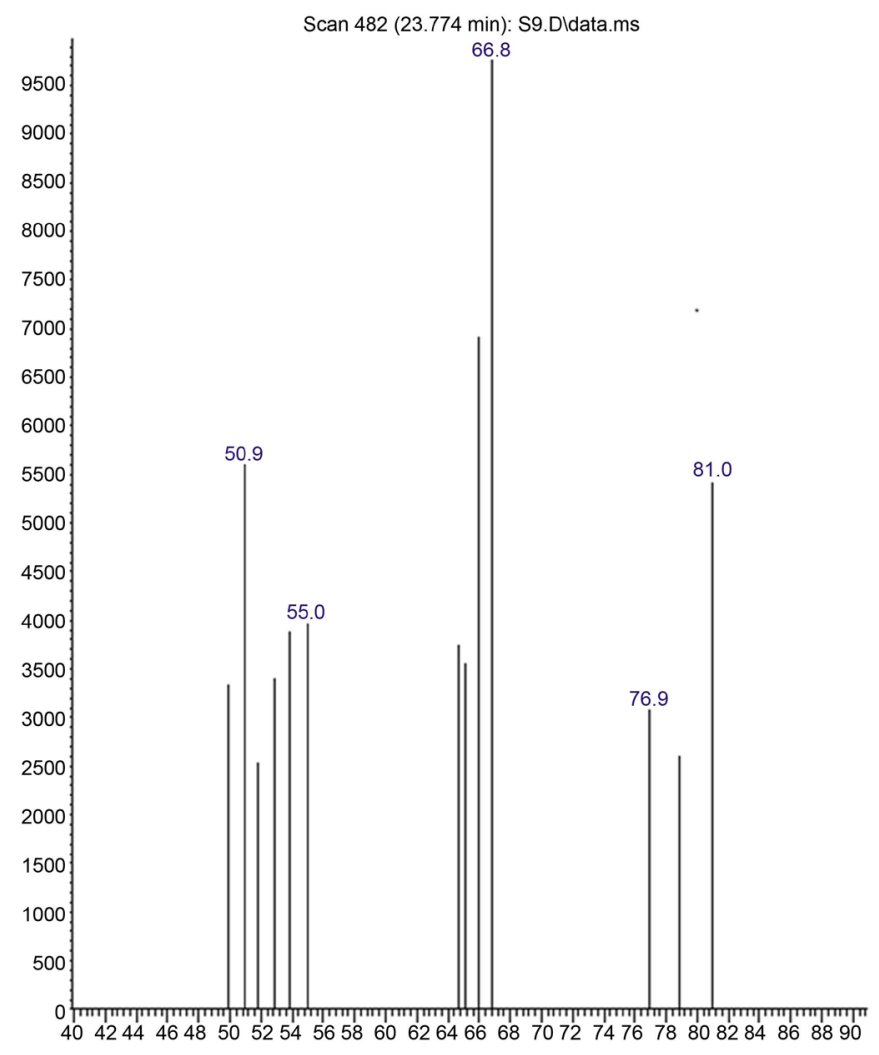
m/z-->

Figure 2. GC-MS chromatogram of $C$. longa.

Abundance

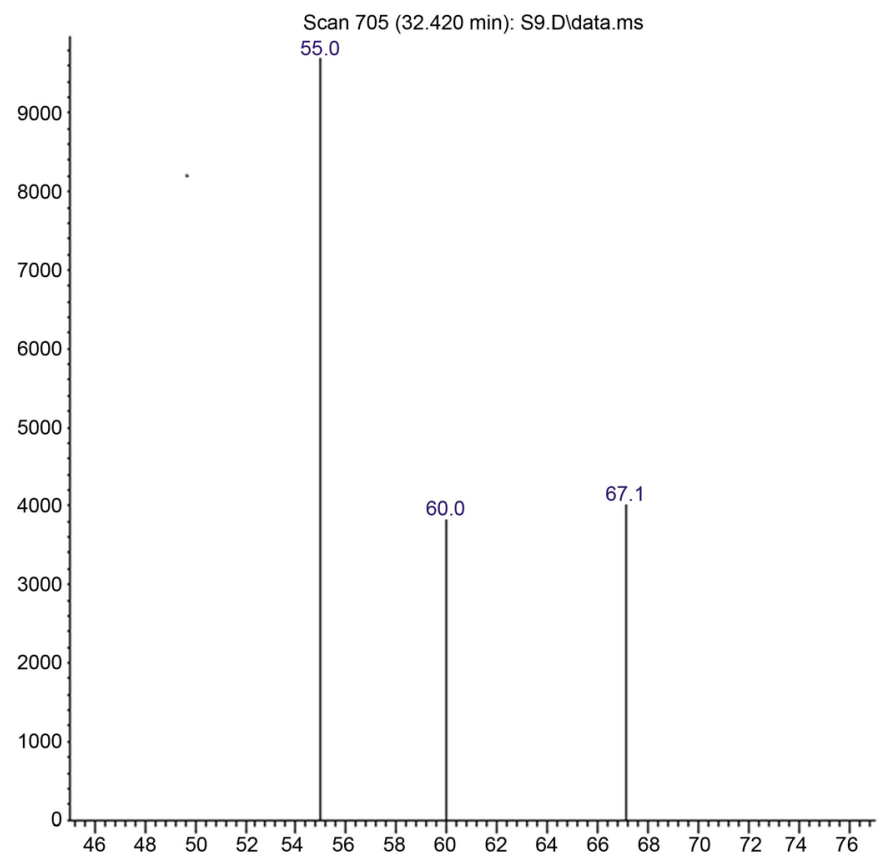

$\mathrm{m} / \mathrm{z}-->$

Figure 3. GC-MS chromatogram of C. longa. 
Abundance

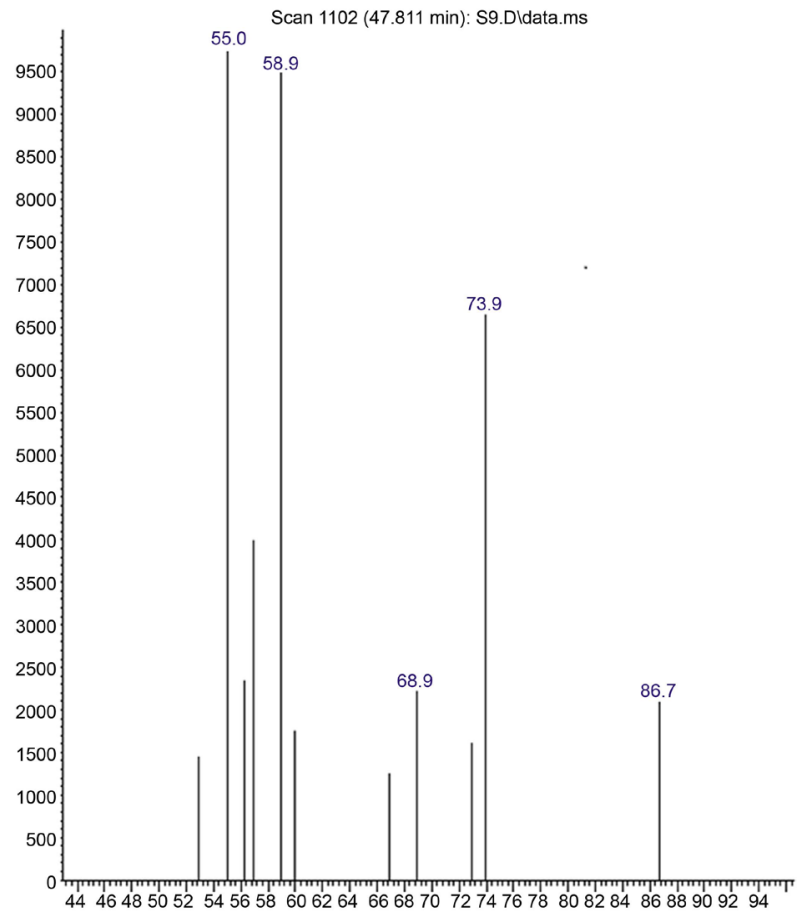
$\mathrm{m} / \mathrm{z-->}$

Figure 4. GC-MS chromatogram of C. longa.

Abundance

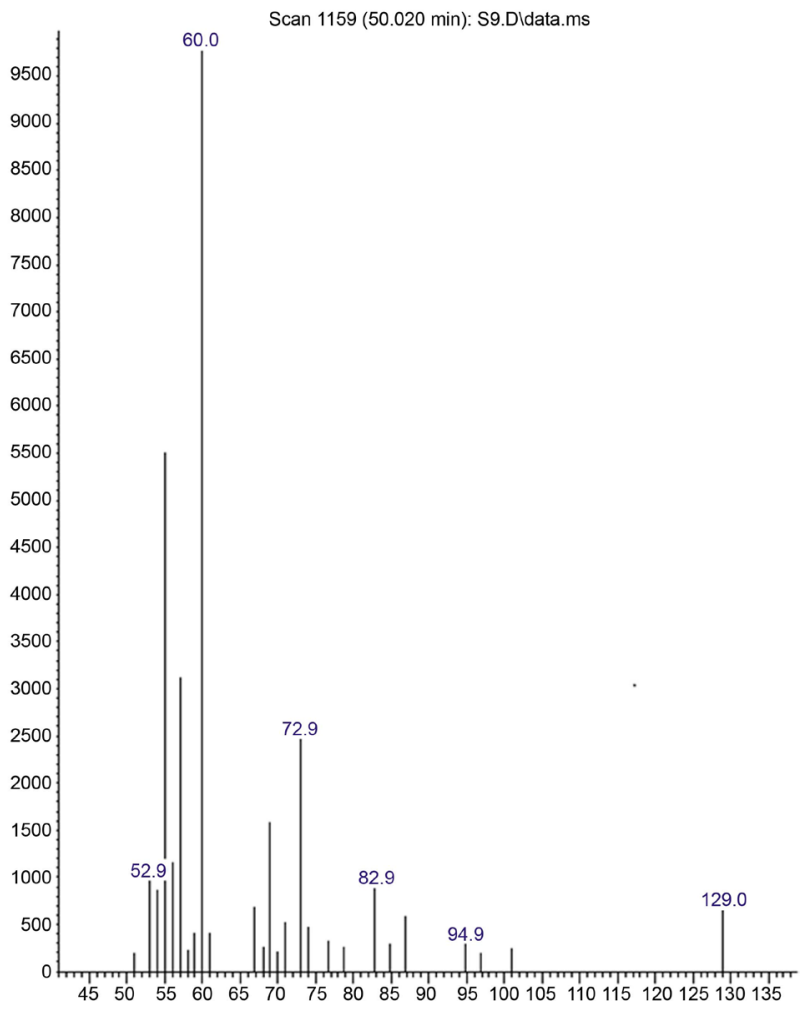

$m / z-->$

Figure 5. GC-MS chromatogram of $C$. longa. 
Table 5. Phytochemical composition of $C$. longa.

\begin{tabular}{|c|c|c|}
\hline Areas & Phenolic Compound & Retention Time (RT) \\
\hline 3.48 & $\begin{array}{l}\text { 1-Azabicyclo [3.1.0] hexane } \\
\text { 0-Allyihyfroxylamine } \\
\text { Pyridine, 2,3,4,5-tetrahydro }\end{array}$ & 55.176 \\
\hline 1.14 & $\begin{array}{c}\text { Butylamine } \\
\text { 0-Allyihyfroxylamine } \\
\text { Hydrazine, 1,2-dimethyl- }\end{array}$ & 55.874 \\
\hline 1.16 & $\begin{array}{c}\text { Urea } \\
\text { Oxalic acid. Butyl cyclobutyl ester } \\
\text { Formic acid hydrazide }\end{array}$ & 56.611 \\
\hline 0.78 & $\begin{array}{l}\text { 2-butanamine, }(\mathrm{S}) \text { - } \\
\text { Formic acid hydrazide } \\
\text { Carbonyl sulfide }\end{array}$ & 59.960 \\
\hline 0.70 & $\begin{array}{c}\text { Propanamide } \\
\text { Carbonyl sulfide } \\
\text { Hydrazine, 1,1-dimethyl }\end{array}$ & 57.503 \\
\hline 0.71 & $\begin{array}{c}\text { Urea } \\
\text { Thiirane } \\
\text { Thiirane }\end{array}$ & 58.355 \\
\hline 0.74 & $\begin{array}{l}\text { Bicyclo [1.1.0] butane } \\
\text { 1,3-Butadiene } \\
\text { 1,3-Butadiene }\end{array}$ & 58.588 \\
\hline 0.70 & $\begin{array}{c}\text { O-Allylhydroxylamine } \\
\text { Urea } \\
\text { Thiirane }\end{array}$ & 59.053 \\
\hline 1.29 & $\begin{array}{l}\text { Bicyclo [1.1.0] butane } \\
\text { 1,3-Butadiene } \\
\text { 1,3-Butadiene }\end{array}$ & 59.247 \\
\hline 0.84 & $\begin{array}{l}\text { Propanal, oxime } \\
\text { Aminoacetonitrile } \\
\text { Ethyl isocyanide }\end{array}$ & 59.519 \\
\hline 0.79 & $\begin{array}{l}\text { Azetidine } \\
\text { Methane, Isocyanato - } \\
\text { Methane, Isocyanato - }\end{array}$ & 59.674 \\
\hline 1.48 & $\begin{array}{l}\text { Propanal, oxime } \\
\text { Aminoacetonitrile } \\
\text { Aminoacetonitrile }\end{array}$ & 59.945 \\
\hline 1.13 & $\begin{array}{l}\text { 2-Butanamine, (s)- } \\
\text { O-Allylhydroxylamine } \\
\text { Thiirane }\end{array}$ & 60.449 \\
\hline 1.11 & $\begin{array}{l}\text { Nitric acid, heptyl ester } \\
\text { Amyl nitrite } \\
\text { (E)-2-Butenylcyclopropane }\end{array}$ & 60.604 \\
\hline 0.79 & $\begin{array}{l}\text { 1,2-Dimethyl cyclopropane } \\
\text { 3-Methylbut-2-en-l-ylpivalate } \\
\text { Aziridine, 1-ethenyl- }\end{array}$ & 60.875 \\
\hline 0.91 & $\begin{array}{l}\text { Ethyl isocyanide } \\
\text { Thiirane } \\
\text { Thiirane }\end{array}$ & 61.108 \\
\hline
\end{tabular}




\section{Continued}

\begin{tabular}{|c|c|c|}
\hline 1.09 & $\begin{array}{l}\text { Azetidine, 1-methyl } \\
\text { Azetidine, 2-methyl } \\
\text { Isobutylamine }\end{array}$ & 61.379 \\
\hline 1.41 & $\begin{array}{l}\text { Thiirane } \\
\text { Hydrazine, 1,2-dimethyl - } \\
\text { Formic acid hydrazide }\end{array}$ & 61.573 \\
\hline 0.97 & $\begin{array}{l}\text { 1,4-pentadiene } \\
\text { Cyclobutane, methylene - } \\
\text { Cyclobutane, methylene - }\end{array}$ & 61.883 \\
\hline 1.48 & $\begin{array}{l}\text { Pyridine, 2,3,4,5-tetrahydro - } \\
\text { 1-Azabicyclo [3.1.0] hexane } \\
\text { Acetonitrile, hydroxyl - }\end{array}$ & 62.426 \\
\hline 1.04 & $\begin{array}{l}\text { Oxirane, 5-hexenyl- } \\
\text { Chloro-methyl-methoxy-amine } \\
\text { Chloro-methyl-methoxy-amine }\end{array}$ & 62.542 \\
\hline 1.16 & $\begin{array}{c}\text { 1-methyl-3-butenyl 3-methyl-3 hydroxybutyl ether } \\
\text { Acetic acid, (aminooxy) - } \\
\text { Hydrazine, 1,2-dimethyl - }\end{array}$ & 62.814 \\
\hline 2.60 & $\begin{array}{c}\text { 1,4,2,5 Cyclohexanetetrol } \\
\text { 11-(2-Cyclopenten-1-yl) undecanoic acid, (+) - } \\
\text { 2-Hepten-1-o1, (E)- }\end{array}$ & 63.202 \\
\hline 1.70 & $\begin{array}{l}\text { 1,5-Pentanediol, 3-methyl- } \\
\text { 3-Buten-1-o1, 3-methyl- } \\
\text { (Aminomethyl) cyclopropane }\end{array}$ & 63.628 \\
\hline 2.59 & $\begin{array}{l}\text { 1-Hexene, 6-bromo- } \\
\text { Sucrose } \\
\text { 2-Heptenal, (E)- }\end{array}$ & 63.861 \\
\hline 1.82 & $\begin{array}{l}\text { Oxirane, 2,2'-(1,4-butanediyl) bis- } \\
\text { 5-Hexen-2-o1 } \\
\text { 3,4-Hexanediol, 2,5-dimethyl - }\end{array}$ & 64.209 \\
\hline 2.42 & $\begin{array}{l}\text { Pentanoic acid, 4-methyl } \\
\text { Amyl nitrite } \\
\text { Oxirane, 2,2'-(1,4-butanediyl) bis- }\end{array}$ & 64.558 \\
\hline 3.42 & $\begin{array}{l}\text { 1,2: 4,5:9, 10-Triepoxydecane } \\
\text { Oxirane, 2,2'-(1,4-butanediyl) bis- } \\
\text { 1,5-Hexadiene, } 3 \text {-methyl }\end{array}$ & 64.830 \\
\hline 3.33 & $\begin{array}{l}\text { Cyclobutanone, 2-methyl -2-oxiranyl } \\
\text { Hexane, 1,6-dichloro- } \\
\text { Sec-Butyl ethyl carbonate }\end{array}$ & 65.062 \\
\hline 1.24 & $\begin{array}{c}\text { 2-Propanamine, N-hydroxy- } \\
\mathrm{CH}_{3} \mathrm{ON}(\mathrm{CH} \#)_{2} \\
\text { 2,3-Epoxyhexanol }\end{array}$ & 65.256 \\
\hline 2.17 & $\begin{array}{l}\text { 4-Cyclopentene -,3-diol, trans- } \\
\text { 1,2:4, 5:9,10-Triepoxydecane } \\
\text { Peopanamide }\end{array}$ & 65.605 \\
\hline 1.06 & $\begin{array}{l}\text { 4-Cyclopentene-1,3-diol, cis- } \\
\text { 2H-Pyran, 2-(3-butynyloxy) tetrahydro- } \\
\text { 2-Methylenecyclohexanol }\end{array}$ & 57.774 \\
\hline
\end{tabular}


Continued

\begin{tabular}{|c|c|c|}
\hline 1.31 & $\begin{array}{l}\text { Thiirane } \\
\text { Hydrazine, 1,1-dimethyl- } \\
\text { Hydrazine, 1,1-dimethyl- }\end{array}$ & 58.007 \\
\hline 1.28 & $\begin{array}{c}\mathrm{CH}_{3} \mathrm{ON}\left(\mathrm{CH}_{3}\right)_{2} \\
\text { Urea } \\
\text { Hydrazine, } 1,1 \text {-dimethyl- }\end{array}$ & 58.101 \\
\hline 0.95 & $\begin{array}{l}\text { 2-Butanamine, }(\mathrm{S}) \\
\text { Isobutylamine } \\
\text { Isobutylamine }\end{array}$ & 58.123 \\
\hline
\end{tabular}

the GC-MS chromatograms obtained after the analysis of the dried C. longa plant for secondary antimetabolites. They include the flavonoids, sterols and tannins. Phenolic compounds are ubiquitously distributed phytochemicals synthesized through the shikimic acid and phenylpropanoid pathways and have been linked to the potentiating effects of human health through the prevention of several diseases due to their antioxidant property. More specifically in a study documented by Huang et al. [35], these may allude the bioactivities of the plant responsible for its chemo-preventive properties such as antioxidant, anti-carcinogenic, anti-inflammatory effects and also contribute to their inducing apoptosis by arresting cell cycle, regulating carcinogen metabolism and ontogenesis expression, inhibiting DNA binding and cell adhesion, migration, proliferation or differentiation and blocking signaling pathways. For example, Subramani and Casmir [36] explained that the flavonoids prevent the oxidation of low-density lipoprotein, lowers the blood levels of cholesterol and triglycerides thereby reducing the risk for the development of atherosclerosis. Okwu [37] also reported the ability of the plant to have vaso-dilatory and inhibitory effects on platelet aggregation thereby preventing coronary heart. On the other hand, saponins have been reported to have beneficial effects on blood cholesterol levels. They bind with bile salts and cholesterol in the intestinal tract and cause a reduction of blood cholesterol by preventing its re-absorption. As noted by $\mathrm{Oa}$ kenfull and Sidhu [38], the non-sugar part of saponins also has antioxidant activity which may help to reduce risk of heart diseases.

\section{Conclusion}

The results of this research work showed that the dried, ground rhizomes of $C$. longa are rich in phytochemicals, proximate, vitamin, amino acids and minerals in appreciable quantities and the presence of these secondary metabolites may explain its efficacy in disease treatment and management with pharmacologic activities as anti-inflammatory, antioxidant, anti-cancer among others. It is worthy of recommendation that this plant as a nutraceutical be incorporated with other such valuable species like ginger in fruit juices, milk shakes and protein shakes for provision of its essential nutrients. This way, through the findings of this study, C. longa will be exploited and further utilized pharmacologically. 


\section{Authors' Contributions}

This work was carried out in collaboration between all authors. Author VHAE designed and supervised the study while GCI carried out the experimental analyses. Authors OGF, OCE and COO managed the analyses of the study and the literature searches. Author UCO wrote the protocol and first draft of the manuscript. All authors read and approved the final manuscript.

\section{Conflicts of Interest}

The authors declare that no conflict of interests exists.

\section{References}

[1] Ononamadu, C.J., Ihegboro, G.O., Owolarafe, T.A., Kailania, S., Fadilua, M., Ezeigwe, O.C., Oshobu, M.L. and Nwachukwu, F.C. (2019) Identification of Potential Antioxidant and Hypoglycemic Compounds in Aqueous-Methanol Fraction of Methanolic Extract of Ocimum canum Leaves. Analytical and Bioanalytical Chemistry Research, 6, 431-439.

[2] Enemor, V.H.A., Oguazu, C.E., Odiakosa, A.U. and Okafor, S.C. (2019) Evaluation of the Medicinal Properties and Possible Nutrient Composition of Citrullus lanatus (Watermelon) Seed. Research Journal of Medicinal Plants, 13, 129-135. https://doi.org/10.3923/rjmp.2019.129.135

[3] Koneri, R.B., Samaddar, S. and Ramaiah, C.T. (2014) Antidiabetic Activity of a Triterpenoid Saponin Isolated from Momordica cymbalaria Fenzl. Indian Journal of Experimental Biology, 52, 46-52. https://doi.org/10.4103/0253-7613.125179

[4] Prasad, S. and Aggarwal, B.B. (2011) Turmeric, the Golden Spice: From Traditional Medicine to Modern Medicine. In: Benzie, I.F.F. and Wachtel-Galor, S., Eds., Herbal Medicine: Biomolecular and Clinical Aspects, 2nd Edition, CRC Press/Taylor \& Francis, Boca Raton, Chapter 13. https://www.ncbi.nlm.nih.gov/books/NBK92752 https://doi.org/10.1201/b10787-14

[5] Chattopadhyan, L., Biswas, K., Bandyo-Padhyay, U. and Banerjee, R.L. (2004) Turmeric and Curcumin: Biological Action and Medicinal Applications. Current Science, 87, 44-53.

[6] Jilani, M.S., Waseem, K. and Habib-Ur-Rehman, M. (2012) Performance of Different Turmeric Cultivars in Deralsmail Khan. Pakistan Journal of Agricultural Sciences, 49, 47-55.

[7] Olatunde, A., Joel, E.B. and Tijjani, H. (2014) Anti-Diabetic Activity of Aqueous Extract of Curcuma longa (Linn) Rhizome in Normal and Alloxan-Induced Diabetic Rats. Researcher, 6, 58-65.

[8] Taoheed, A.A., Tolulope, A.A., Saidu, A.B., Odewumi, O.G., Sunday, R.M. and Usman, M. (2017) Phytochemical Properties, Proximate and Mineral Composition of Curcuma longa Linn. and Zingiber officinale Rost.: A Comparative Study. Journal of Scientific Research and Reports, 13, 1-7. https://doi.org/10.9734/JSRR/2017/32623

[9] Nwaekpe, J.O., Anyaegbunam, H.N., Okoye, B.C. and Asomugha, G.N. (2015) Promotion of Turmeric for the Food/Pharmaceutical Industry in Nigeria. American Journal of Experimental Agriculture, 8, 335-341. https://doi.org/10.9734/AJEA/2015/16517

[10] Chanda, S. and Ramachandra, T.V. (2019) Phytochemical and Pharmacological 
Importance of Turmeric (Curcuma longa): A Review. Research \& Reviews: A Journal of Pharmacology, 9, 16-23.

[11] Olojede, A.O. and Nwokocha, C.C. (2011) A Decade of Research on Minor Root and Tuber Crops at NRCRI: The Contribution towards Food Sufficiency and Economic Empowerment in Nigeria, In: Amadi, C.O., Ekwe, K.C., Chukwu, G.O., Olojede, A.O. and Egesi, C.N., Eds., Root and Tuber Crops Research for Food Security and Empowerment, 387-396.

[12] Luthra, P.M., Singh, R. and Chandra, R. (2001) Therapeutic Uses of Curcuma longa (Turmeric). Indian Journal of Clinical Biochemistry, 16, 153-160. https://doi.org/10.1007/BF02864854

[13] Abdel-Lateef, E., Mahmoud, F., Hammam, O., El-Ahwany, E., El-Wakil, E., Kandil, S., Taleb, H.A., El-Sayed, M. and Hassenein, H. (2016) Bioactive Chemical Constituents of Curcuma longa L. Rhizomes Extract Inhibit the Growth of Human Hepatoma Cell Line (Hepg2). Acta Pharmaceutica, 66, 387-398.

https://doi.org/10.1515/acph-2016-0028

[14] Akram, M. (2010) Curcuma longa and Curcumin: A Review. Romanian Journal of Biology Plant Biology, 55, 65-70.

[15] AOAC (2000) Official Methods of Analysis. Association of Official Analytical Chemists, Washington DC.

[16] Kirk, R.S. and Sawyer, R. (1991) Pearson's Composition and Analysis of Foods. 9th Edition (Student Edition), Addison Wesley Longman Ltd., 33-36.

[17] Zakaria, M., Simpson, K., Brown, P. and Krstulovic, A. (1979) Use of Reverse Phase HPLC Analysis for the Determination of Provitamin A Carotenes in Tomatoes. Journal of Chromatography, 176, 109-117. https://doi.org/10.1016/S0021-9673(00)92091-0

[18] American Public Health Association (1995) Standard Methods for the Examination of Water and Wastewater. 19th Edition, American Public Health Association Inc., New York.

[19] Elkin, R.G. and Griffith, J.E. (1985) Amino Acid Analysis of Feedstuff Hydrolysates by High Performance Liquid Chromatography. Journal-Association of Official Analytical Chemists, 68, 1028-1032. https://doi.org/10.1093/jaoac/68.5.1028

[20] Ikpeama, A., Onwuka, G.I. and Nwankwo, C. (2014) Nutritional Composition of Tumeric (Curcuma longa) and Its Antimicrobial Properties. International Journal of Scientific and Engineering Research, 5, 1085-1089.

[21] Imoru, A., Onibi, G.E. and Osho, I.B. (2018) Nutritional and Biochemical Compositions of Turmeric (Curcuma longa Linn) Rhizome Powder-A Promising Animal Feed Additive. International Journal of Scientific and Engineering Research, 9, 424-429.

[22] Rajkumari, S. and Sanatombi, K. (2017) Nutritional Value, Phytochemical Composition, and Biological Activities of Edible Curcuma Species: A Review. International Journal of Food Properties, 20, S2668-S2687.

https://doi.org/10.1080/10942912.2017.1387556

[23] Ogidi, O.I., Esie, N.G. and Dike, O.G. (2019) Phytochemical, Proximate and Mineral Compositions of Bryophyllum pinnatum (Never Die) Medicinal Plant. Journal of Pharmacognosy and Phytochemistry, 8, 629-635.

[24] Bamishaiye, E.I., Olayemi, F.F., Awagu, E.F. and Bamshaiye, O.M. (2011) Proximate and Phytochemical Composition of Moringa oleifera Leaves at Three Stages of Maturation. Advance Journal of Food Science and Technology, 3, 233-237. 
[25] Ayoola, P.B. and Adeyeye, A. (2009) Proximate Analysis and Nutrient Evaluation of Some Nigerian Pawpaw Seeds Varieties. Science Focus, 14, 554-558.

[26] Margaret, L. and Vickery, B. (1997) Plant Products of Tropical Africa. Macmillan in College, London.

[27] Okaka, J.C. and Okaka, A.N.C. (2001) Food Composition Spoilage and Shelf Life Extension. Ocjare Academic Publisher, Enugu, 54-56.

[28] Hartwig, A. (2001) Role of Magnesium in Genomic Stability. Mutation Research, 475, 113-121. https://doi.org/10.1016/S0027-5107(01)00074-4

[29] Wolf, F.I. and Cittadini, A. (2003) Chemistry and Biochemistry of Magnesium. Molecular Aspects of Medicine, 24, 3-9. https://doi.org/10.1016/S0098-2997(02)00087-0

[30] Pasternak, K., Kocot, J. and Horecka, A. (2010) Biochemistry of Magnesium. Journal of Elementology, 15, 601-616.

[31] Ogbodo, U.C., Emeh, J.K., Neboh, E.E., Ocheni, S.C., Maduka, I.G. and Ikekpeazu, E.J. (2010) Estimation of Intracellular Magnesium Concentrations and Assay of ATPase Activity in Red Blood Cells of Normal and Sickle Cell Subjects Resident in Enugu Urban Area. International Journal of Biological and Medical Research, 1, 149-152.

[32] Cowan, J.A. (1995) Introduction to the Biological Chemistry of Magnesium Ion. In: The Biological Chemistry of Magnesium, VCH, New York, 1-23.

[33] Afolabi, G., Oluwade, A. and Tunde, O. (1995) Estimation of Proximate and Mineral Composition of Some Tropical Crops. African Agricultural Journal, 21, 103.

[34] National Research Council (1989) Recommended Dietary Allowance. National Academy Press, Washington DC.

[35] Huang, W.Y., Cai, Y.Z. and Zhang, Y. (2010) Natural Phenolic Compounds from Medicinal Herbs and Dietary Plants: Potential Use for Cancer Prevention. Nutrition and Cancer, 62, 1-20. https://doi.org/10.1080/01635580903191585

[36] Subramani, S. and Casmir, C.A. (2002) Flavonoids and Antioxidant Activity of Georgia Grown Vidalia Onions. Journal of Agricultural and Food Chemistry, 50, 5338-5342. https://doi.org/10.1021/jf020333a

[37] Okwu, D.E. (2001) Evaluation of the Chemical Composition of Indigenous Spices and Flavoring Agents. Global Journal of Pure and Applied Sciences, 7, 455-459. https://doi.org/10.4314/gjpas.v7i3.16293

[38] Oakenfull, D. and Sidhu, G. (1990) Saponins-A Useful Treatment for Hypercholesterolemia. European Journal of Clinical Nutrition, 44, 79-88. 